\title{
Sanomalehden alakerta Virossa viime vuosisadan lopulla
}

Proosakirjallisuuden tiivis yhteys sanomalehdistön kehitykseen on tiettävästi tavallinen ilmiö kaikkien kansojen kirjallisessa elämässä. Sanomalehdistö ei hyödytä ainoastaan kirjallisuuden pienoismuotoja — kertomusta, novellia, humoreskia —, vaan yhtä paljon myös laajaa muotoa, romaania. Ranskassa sanomalehtiromaaneja tavataan jo 17. vuosisadan lopussa, ja Saksassa ne saavat huomattavan merkityksen viime vuosisadan alussa. ${ }^{1}$

Viron kulttuurielämän taso ei viime vuosisadan loppupuolella ollut erityisen korkea, mutta tilanne parani juuri silloin hyvin nopeasti. Sama tendenssi kuvastuu tietysti myös silloisessa sanomalehdistössä. Venäjällä oli kansansivistyksen tila vielä vuosisadan vaihteen edellä sangen surullinen. Sen vuoksi ei voi edellyttää, että valtakunnan hallitus olisi rajamaissakaan tehnyt kouluolojen järjestämiseksi mitään mainittavaa. Mikäli Baltian maissa annettiin kouluille tukea, se kohdistui etupäässä ylimpien luokkien erityiskouluihin; maan alkuperäisen väestön koulut jätettiin suuremmaksi tai pienemmäksi osaksi paikallisen talonpoikaisväestön yksityisasiaksi. Se, mitä Virossa, Suomessa ja Liivinmaalla saatiin aikaan kansanopetuksen alalla, oli paikallisen asujamiston oma-aloitteisuuden ja sitkeän sivistyspyrkimyksen ansiota.

Novgorodin näyttelyssä esillä ollut "kansansivistyksen kartta" luonnehtii hyvin vielä v. 1896 vallinneita kouluoloja. Venäjän karttaan on siinä merkitty vaaleilla väreillä ne alueet, joissa koulunkäynti on intensiivisintä ja parhaiten järjestettyä, tummemmilla väreillä taas ne alueet, joissa tilanne on kehnompi. Kartasta erottuvat vaa-

1 W. Haacke, Handbuch des Feuilletons II. Emsdetten 1952, s. 250-251. 
leimpina läikkinä Suomi ja Liivinmaa, joissa on 6 koulua käyvää lasta 100 asukasta kohti; vaaleita alueita ovat edelleen Viron ja Kuurinmaan kuvernementit, joissa koulua käyvien prosenttiluku on 5-6, ja näiden lisäksi vielä Krimi, tunnettu balttilaisten ja saksalaisten siirtolaisten alue. Suunnattoman valtakunnan muut alueet ovat kaikki surkuteltavan synkkiä. ${ }^{2}$ Lukutaitoon nähden Venäjä oli koko viime vuosisadan ajan viimeisellä sijalla Euroopassa. Vielä v. 1870, jolloin analfabeettien määrä Saksassa oli laskenut 2,37 \%:iin ja Ruotsissa 1,90\%:iin asujamistosta, Venäjällä oli analfabeetteja $78,66 \% .^{3}$ Kun olot olivat tällaiset, ei voi odottaa, että lukutaito olisi Virossakaan ollut yleinen silloin, kun sanomalehdistö otti ensi askeleitaan. Kirjailija A. Kitzberg mainitsee, että hänen isänsä nuoruudessa oli Laatren kunnassa ollut vain kolme kirjoitustaitoista miestä. ${ }^{4}$ Vuosisadan viimeisellä kymmenluvulla Viron kuvernementti oli kuitenkin lukutaidon suhteen ensimmäisellä sijalla Venäjän valtakunnassa: 79,9\% lukutaitoisia. Kansakoulua pitemmälle pääseminen oli kuitenkin silloinkin harvinaista - tuskin kaksi prosenttia virolaisista oli saanut ylempää kouluopetusta, ja yliopistosivistystä saaneita oli vain puoli prosenttia. ${ }^{5}$ Sivistyksellisen kurjuuden syynä oli tietenkin kansan taloudellinen ja yhteiskunnallinen hätä. Kun elettiin suuren köyhyyden puristamina, syötiin akanaleipää ja asuttiin pimeissä savupirteissä, kun oli pakko tehdä raskasta ruumiillista työtä aamuvarhaisesta iltamyöhään ja usein öisinkin - kuinka voitiin silloin ajatella kirjallisuuden hankkimista tai lukemista. Lautalattioita ja lasi-ikkunoita ruvettiin tosin asumuksiin hankkimaan jo menneen vuosisadan puolivälin jälkeen, mutta savupiiput ilmaantuivat vasta 1870-luvulla, ja suunnilleen samaan aikaan tulivat käytäntöön myös esim. lamppu ja kello. Vielä vuosisadan loppuvuosinakin voi sanomalehdistä löytää sellaisia lohduttomia tietoja kuin kuvauksessa Juurun pitäjän oloista, jossa kerrotaan, että "kahta koulua ja moisiota lukuun ottamatta yhdessäkääan talossa ei ole savupiippua". Virumaalta Kadrinan pitäjästä lehti kirjoittaa samaan aikaan: "Palan kunnassa ei ole ainoatakaan savupiipullista taloa." Simunan pitäjästä taas ilmoi-

2 Postimees 1896/144 - Rahvahariduse kaart.

${ }^{3}$ Teataja 1902/108 - Kirja-oskamisest.

${ }^{4}$ A. Kitzberg, Ưhe vana tuuletallaja noorpõlve mälestused. 2. tr. Stockholm 1957, s. 21.

5 E. Laaman, Eesti ühiskond. Tartu 1936, s. 27. 
tetaan, että 'Mooran kunnassa — — ei yhdessäkään talossa ole ikkunaa". ${ }^{6}$ Kun näihin savupirtteihin alkoi joutua painettuja kirjoja, hengellisellä kirjalla oli aluksi etuoikeus. Hengelliset teokset säilyttivät kauan valta-asemansa muun kirjallisuuden rinnalla. ${ }^{7}$ Maallista kirjaa pidettiin laajoissa piireissä vielä kauan "loruna" ja sen lukemista syntinä. Sitä paitsi maallinen kirjallisuus oli alakynnessä myös levittämisvaikeuksien takia. Kirjakauppoja oli harvassa, ja kirjoja myytiinkin kulkukauppiaiden välityksellä tai markkinoilla, kun taas hengellịsiä teoksia levittivät papit kirkkojen kautta. Runouden alalla saattoi virolainen kirjallisuus kaikesta huolimatta saavuttaa muutamia hyviä tuloksia, mistä on todistuksena esim. F. R. Kreutzwaldin ja L. Koidulan tuotanto; proosakirjallisuuden tilan pelastajaksi ilmaantui sanomalehdistö. Aiheellisesti voi väittää, että "sanomalehdistö kasvatti ensimmäiset virolaiset proosakirjailijat". ${ }^{8}$

J. V. Jannsenin saatua v. 1857 luvan sanomalehden julkaisemiseen — se merkitsi pysyvän sanomalehdistön alkua Virossa — hänen lehtensä "Perno Postimees ehk Näddalileht" (Pärnun Postimies eli Viikkolehti) sisälsi pian hengellisen liitteen rinnalla myös maallisen lukemiston "Jutto-Tubba", jossa oli kansanomaisia tarinoita ja käännöskertomuksia. Julkaisija kiinnitti siihenkin suurta huomiota, ja "tarinatupa" muodostui tärkeäksi välineeksi Jannsenin kansansivistyksellisessä toiminnassa, jonka tarkoituksena oli "sytyttää lisää kynttilöitä, että virolainen pimeä pirtti kävisi valoisammaksi".9 Vertailun vuoksi mainittakoon, että samana vuonna, jolloin "Perno Postimees" lehden ensimmäinen numero pääsi julkisuuteen, Suomessa oli jo kymmenen sanomalehteä ja että esim. Elias Lönnrot käsitti niillä olevan suuren merkityksen kaunokirjallisuuden kehitystä ajatellen. ${ }^{10}$

Jannsenin sanomalehdestä alkaen virolainen lehdistö on sangen merkittävästi edistänyt proosakirjallisuutta. Käsitteet kirjailija ja

\footnotetext{
6 J. Kõpp, Laiuse kihelkonna ajalugu. Tartu 1937, s. 331; Postimees 1892/ $183-184$.

? R. Antik, Eesti raamat 1535-1935. Tartu 1936, s. 27.

8 V. Ridala, Eesti kirjanduse ajalugu III. Tartu 1929, s. 145.

- Perno Postimees 1862/21.

10 Pysy Suomessa pyhänä. Suomalaisen Kirjallisuuden Seuran esimiesten puleita vuosina 1834-1946. Toimitt. Eino Nivanka. SKS Toimituksia 268. Helsinki 1961 , s. $50-51$.
} 
lehtimies olivat vielä kauan miltei synonyymeja. Ellei kirjailija joutunut suorastaan etsiytymään työhön sanomalehden toimitukseen, hänen ainakin oli pakko käyttää teostensa julkaisemiseen sanomalehden palstatilaa, niin kuin on tehnyt suuri osa virolaisista kirjailijoista. Viron kirjallisuuden historia ei voi jättää tärkeimpien kirjailijain joukossa mainitsematta sellaisia sanomalehdentoimittajia kuin Jannsen, Jakobson, Järv, Grenzstein ja Hermann, mutta monien muidenkin kirjailijain nimet liittyvät tiiviisti sanomalehdistöön. Ei ollut mitään erikoista siinä, että Juhan Liiv saatuaan "Virulane" lehdeltä kutsun tulla toimitukseen apulaiseksi kirjoittaa tuttavalleen vuoden 1885 syksyllä, että lehden toimittaja kutsuu häntä Tallinnaan, "jossa kuuluu olevan saatavana eräs hyväpalkkainen kirjailijan toimi". ${ }^{11}$ Onnellisimmin pystyi kysymyksen ratkaisemaan Eduard Vilde, joka oli suurimman osan luomisajastaan sanomalehtien kaunokirjallisen osaston toimittajana. Työhön liittyi julkaisijan kanssa tehty kannustava sopimus, jonka mukaan hänen oli kirjoitettava määräluku määrämittaisia kertomuksia. "Tavallisen toimitustyön lisäksi minun oli vielä kirjoitettava lehteen neljä määrämittaista alkuperäistä kertomusta vuodessa. Tästä ehdosta en päässyt myöhemminkään, työskennellessäni seuraavien 13 vuoden kuluessa muissa lehdissä", hän kertoo lehtityöstään vuosisadan viimeisellä kymmenluvulla. ${ }^{12}$ Joskus hän valittaa, että muut toimituksessa esiintyvät tehtävät vievät liian paljon aikaa, vaikka hänen sopimuksen mukaan pitäisi toimittaa vain kaunokirjallista osastoa: "Minä en ehdi päästä käsiksi työsarkaan, mikä minulle määrättiin, nimittäin följetonistiseen ainekseen, vaan välityöt vievät aamupäivän kokonaan." ${ }^{13} \mathrm{Mahdolli-}$ suuksia myöten hän kuitenkin pysyy uskollisena lehden alakerralle pari vuosikymmentä ja vielä kuulun trilogiansa (Mahtra sõda; Kui Ania mehed Tallinnas käisid ; Prohvet Maltsvet) ilmestymisen aikoihin hän on "pääasiallisesti feuilletoni-toimittajana". ${ }^{14}$ On luonnollista, että niin luomisvoimainen kirjailija kuin Vilde kykenee kahden vuosikymmenen toiminnallaan johtavissa sanomalehdissä vaikuttamaan myös kertomaosaston ilmeeseen, muotoilemaan koko virolaisen sano-

11 F. Tuglas, Juhan Liiv, 2. tr. Tallinn 1958, s. 98.

${ }^{12}$ E. Vilde - M. Kampmannille 1912. [E. Vilde] Artikleid ja kirju. Toimet. P. Rummo j.t. Tallinn 1957, s. 431-432.

${ }^{13}$ E. Vilde - J. H. Vahtrikille 1894, m.t., s. 318.

14 Päevaleht 1909/65. 
malehdistön kaunokirjallista liitettä. Suureksi osaksi juuri omasta ansiostaan hän saattoi uuden vuosisadan alussa sijoittaa historiallisen trilogiansa sanomalehden kertomusosastoon ja kerskaillen vakuuttaa, että vähemmälle kuin 6000 lukijalle hän ei rupeakaan kirjoittamaan. ${ }^{15}$

"Perno Postimees", ensimmäinen virolainen lehti, ilmestyi viikkolehtenä, jonka sivukoko $(26 \times 20 \mathrm{~cm})$ muistutti nykyaikaisen käsityksen mukaan pikemminkin kirjaa kuin sanomalehteä. Pian alkoi kuitenkin ilmaantua uusia ja suurempiformaattisia. Uuden lehden perustaminen oli vaivalloinen yritys, mutta julkaisulupia tavoiteltiin sangen sitkeästi. C. R. Jakobson oli v. 1871 kirjoittanut viranomaisille jo 50 kirjettä saadakseen luvan "Sakala" lelıden julkaisemiseen, mutta vastaus oli aina kieltävä. Vasta vuoden 1877 lopussa, hellittämättä ja urheasti ajettuaan asiaa jo yhdeksän ruotta, hänen onnistui saada sanomalehtilupa. ${ }^{16}$ Kymmenen vuotta myöhemmin, siis kolme vuosikymmentä Jannsenin sanomalehden perustamisen jälkeen, ilmestyi jo kymmenen vironkielistä sanomalehteä. Useimmat niistä olivat Jannsenin lehteä huomattavasti kookkaampia ja kaikissa oli kertomusosasto, joko alakertana tai erillisenä liitteenä. Julkaisijat tiesivät hyvin, että juuri kertomusosasto oli lukijoiden suosima: useilla ei riittänyt kiinnostusta uutisiin ja pääkirjoituksiin, vaan heidän ainoaa lukemistansa oli kertomusosasto. Lehtien mainoksissa sitä näkee usein korostettavan: luvataan tarjota "hauskoja kertomuksia" ja ilmoitetaan jonkun tunnetun kirjailijan avustavan kertomusosastoa. Lehtien liitteinä julkaistaan jopa kirjan formaattiin taitettuja kaunokirjallisia lisälehtiä, ja liikemiehen ja keinottelijan J. Kôrvin "Valgus" lehdestä aikalaiset muistelevat, että siinä oli useitakin kertomusliitteitä ja että "päälehti lopuksi katosi kokonaan kukkuraisten kertomusliitteidensä alle". ${ }^{17}$ Noiden kolmen vuosikymmenen kuluessa - virolaisen sanomalehdistön -alusta siihen saakka, kun Vilde syyskuussa 1888 aloitti sanomalehtityönsä "Virulane" lehden julkaisijan J. Järven oppipoikana — lehtien määrä oli noussut yhdestä kymmeneen. Kertomusosasto sen sijaan oli samana aikana paisunut Jannsenin "tarinatupaan" verrattuna runsaasti 50-kertaiseksi. Kyseen-

15 Päevaleht 1909/64 - B. Linde, L'art pour l'art.

${ }_{16}$ R. Antik, Ajakirjanduse tähendusest Eesti arengus. Raamatu osa Eesti arengus. Tartu 1935, s. 248.

17 L. Suburg, Suburgi perekond. Eesti Kirjandus 1924, s. 254. 
alaista oli vain se, miten järkevästi käytettiin sitä suurta palstatilaa, jonka virolainen lehdistö nyt saattoi tarjota kaunokirjallisuuden palvelukseen.

Kertomusosaston laatua käsittelevissä puheenvuoroissa pohditaan kysymystä, pitäisikö sanomalehtikertomuksen olla pitkä vai lyhyt, ja mielipiteet käyvät ristiin. Grenzstein suosittelee lyhyitä, sillä pitkille ei hänen mielestään ole tilaa. ${ }^{18}$ Vilde on päinvastaista mieltä ja neuvoo lehden avustajia: "Eräästä asiasta tahtoisin teille muistuttaa: älkää tuhertako lyhyitten pätkien parissa — siitä kansa ei pidä."19 Paljon olennaisempi on kuitenkin ongelma, joka pitkän aikaa pysyy vaikeana kïstakysymyksenä: onko etusijalle asetettava alk u p eräist e os vai käännös. Juuri Vildellä näyttää olevan suurempi ansio kuin kenelläkään muulla siinä, että alkuperäisteokset lopuksi kuitenkin pääsevät voitolle. Väittely käy kiivaana puolin ja toisin, mutta Vilde osoittaa käytännöllisellä työllä, että alkuperäisteoksille kuuluu kunniapaikka virolaisen sanomalehden kertomusosastossa ja että ne saavat osakseen lukijakunnan suuren suosion.

Oli käynyt ikään kuin itsestään selväksi, että maallinen kertomus, ilmestyipä se sanomalehdessä tai kirjasena, on käännös. Naiivi lukija tuskin kiinnitti asiaan huomiota. Sanomalehdentoimittajan oli vaivatonta täyttää kertomusosasto saksalaisista perhelehdistä tai muualta otetuilla seikkailukertomuksilla, ja kääntäjiä — ellei hän kääntänyt itse — oli saatavissa pienellä palkalla. Arvosteluissa puhuttiin harvoin ala-arvoisista "nokkosista" tai "akanoista", tavallisempaa oli, että julkaisija liitti näihin kauhu- ja seikkailukertomuksiin lämpimiä suositussanoja. Lukijatkin toivoivat mieluimmin joko sentimentaalisia "haikeita ja suloisia" kertomuksia tai sitten niin kaameita, "että ihokarvat nousevat pystyyn lukiessa". Kôrvin tapaisille liike-lehtimiehille tilanne oli tietenkin kaikin puolin mieleen. Se, että vaatimatonta lukuhalua jouduttiin tyydyttämään käännöksillä, ei tietenkään ollut luonteenomaista vain virolaiselle lukijakunnalle. Samoin olivat asiat niissäkin maissa, joiden oma kirjallisuus oli jo paljon korkeatasoisempaa. $^{20}$

18 Olevik $1891 / 51$.

19 E. Vilde - A. Buschille 1889. [E. Vilde] Artikleid ja kirju, s. 294.

${ }^{20} \mathrm{Ks}$. esim. J. Mortensen, Från Aftonbladet till Röda rummet. Stockholm 1905, s. 261. 
Hyvin pian alkoi kuitenkin kuulua myös yksityisiä auktoritatiivisia ääniä liiallista käännöstulvaa vastaan. Tilanne aiheutti huolta jo "Iauluisä" Kreutzwaldille, joka valitti:

Lukijaimme turmeltunut maku kaipaa ravintoa, joka on kaameaa ja eriskummallista, astuu usein hulluin askelin todellisuuden rajojen yli ja heittää kuperkeikkaa, niin että varpaat eivät kosketa maanpintaa: sellainen hengenvaarallinen tarina on heidän herkkuaan. ${ }^{21}$

Käännösten sijaan Kreuzwald suosittelee alkuperäisteoksia. Hänen mielestään virolaisen kirjallisuuden pitäisi "poimia jutunjuuret kylänraiteilta". Samaan aikaan M. Jürgens kirjaluettelossaan pahoittelee huonoja käännöksiä ja valittaa, että liian helposti päästetään painoon "tyhjiä palkoja":

Joka vain vähänkin osaa töherrellä, se on kirjan kirjoittaja! Käy karvoista kiinni ja kääntää kiskoo puoliraa'asti saksasta viroon, ja kirja onkin valmis! ${ }^{22}$

Käännettävät kertomukset olivat avuttomia, ja sitä paitsi ne muuttuivat vielä kääntäjän käsissä, tavallisesti vielä kehnommiksi. Paitsi että teksti jo kielellisten vaikeuksien vuoksi auttamattomasti vääristyi, kääntäjä piti vielä velvollisuutenaan "korjata" originaalia ja muutella sitä oloihin sopivaksi. Hän voi ilman vähintäkään omantunnon vaivaa, vieläpä ylpeillen sanoa: 'Koska saksalainen kirjailija on sangen monessa asiassa mennyt liiallisuuksiin, minä jouduin sommittelemaan kappaleen aivan uudestaan, ei ainoastaan kääntämään." ${ }^{23}$ Ansiokas kääntäjä M. J. Eisen neuvoo v. 1891 nuorta E. Aspea: "Teidän ei tarvitse milloinkaan kääntää sanasta sanaan; mitä vapaammin se tapahtuu, sitä parempi." ${ }^{24}$ Vielä uuden vuosisadan alussa vasta papiksi valmistunut J. Bergmann pitää sanomalehden jatkoromaanin käännöstään jopa alkuperäistä teosta parempana, koska hän on paikoin lyhennellyt sitä, paikoin soluttanut siihen omia lisäyksiään ja katkelmia toisten kirjailijain teoksista: "Vironkielisessä käännöksessä on pidetty huolta siitä, että kertomusta voisi lukea ja esittää kaikkialla ; alkukielisessä muutamat kohdat ovat perheelle ja lapsille hie-

${ }^{21}$ F. R. Kreutzwald, Paar sammokest rändamise-teed. Tartu 1861, s. 19.

${ }_{22}$ M. Jürgens, Ramatute nimme-kirri ehk katalog. Tallinn 1864, s. 4.

${ }_{23}$ J. Kärner, Eesti näitelava 19. sajandil. Lehed tullde. Tallinn 1958, s. 31.

${ }^{24}$ A. Raag, Elisabeth Aspe elu ja looming. Tartu 1928, s. 27. 
man sopimattomia.” ${ }^{25}$ Sanomalehdissä jätetään usein sekä tekijän että kääntäjän nimet mainitsematta. Jos kääntäjä kuitenkin mainitaan, se usein tehdään tavalla, joka antaa oikeuden alkutekstin muuttamiseen: kääntäjän nimen eteen sijoitetaan sanat "alkutekstin mukaan kertonut" tai "edelleen kertonut".

Tällaiset tyhjänpäiväisten seikkailu- ja kauhukertomusten mukaelmat, ilmestyivätpä ne sanomalehden alakertojen "lohikäärmeinä" ja "merikäärmeinä" tai erillisinä vihkoina, tukahduttavat alkuperäisen proosan. Jotkut sanomalehdenjulkaisijat suosivat niitä kaupallisista syistä, toisten asenne on taas aivan erilainen. Jos vertailee joiAenkin 1880-luvun keskivaiheilla, Vilden ensimmäisten lehtimiesvuosien aikoihin, ilmestyneiden sanomalehtien kertomusosastoja, ilmenee tuntuvaa erilaisuutta, ja Vilden alkuperäisen tuotannon vaikutus no!nsee näkyviin.

A. Grenzsteinin lehti "Olevik" julkaisee 1882-1886 johdonmukaisesti käännöksiä, joiden joukossa harvoin on mitään arvokasta. Mainitsemisen arvoisia ovat vain Turgenjevin "Majatalo", Jókain "Jumalien linnoitus" ja Gogolin "Reviisori", muu aineisto on lainattu kolmannen luokan kirjailijoilta. Tunnustetun Baltian-saksalaisen kirjailijan T. H. Panteniuksen suosittua Liivinmaan historiasta kertovaa romaania "Die von Kelles" ryhdytään julkaisemaan v. 1885, mutta käännöksen ilmestyminen katkeaa suureen skandaaliin. ${ }^{26}$ Alkuperäisteosten puuttumista puolustellaan väitteellä, että "uskomme kansan lukevan mielellään sellaisia tarinoita, joiden näyttämöinä ovat suuret kaupungit ja komeat linnat". ${ }^{27}$

J. Kôrvin "Valgus" on suurikokoinen lehti ja sen kertomusliitteet, kuten mainittu, ovat lukuisat. Alkuperäisiä kertomuksia lehti ei mainittuina vuosina kuitenkaan tarjoa juuri ollenkaan. Käännökset ovat peräisin satunnaisista ajanvietekertomuksista, usein venäläisistä lähteistä, ja tavallisesti ne ovat suuren venäläistäjän ja keinottelijan Kôrvin tai hänen vaimonsa tekemiä. Parempaa ulkomaista kirjallisuutta edustavat Jókain "Vanki" ja "Mustat timantit". Alkuperäisteoksista ovat lehteen joutuneet v. 1882 J. Johanson-Pätnin "Jaak

\footnotetext{
${ }^{25}$ Postimees 1902/90.

26 H. Salu, "Kelleste omad". Ühe romaanitôlke ajaloost. Virittäjä 1960, s. $384-385$.

${ }^{27}$ Olevik 1883/16.
} 
ja Miina" 28 ja v. 1886 E. Bornhöhen matkakirjeet "Matka LänsiEurooppaan". Viimeksi mainittu oli ensin luvattu toiseen lehteen, mutta joutui jotenkin Kôrvin "Valguseen". ${ }^{29}$ On kuvaavaa, että "Valgus" usein julkaisee soimaavia kirjoituksia alkuperäisistä kertomuksista, kun niitä joskus ilmestyy muissa lehdissä, ja kehuu omia käännöksiään. ${ }^{30}$ Mutta äkkiä Kôrv tekee täyskäännöksen siihenastisista mielipiteistään: v. 1887 hän julkaisee lehdessään kertomuksen "Varma päämäärä", jonka alaotsikossa sen sanotaan olevan "virolainen kertomus" ja jonka kirjoittajaksi mainitaan Jakob Kôrv. Samana vuonna seuraa vielä toinenkin pitkähkö kertomus, jonka jälleen väitetään olevan julkaisijan oma kirjoittama alkuperäisteos. Vastaus kysymykseen, miksi Kôrv, siihenastinen alkuperäisteosten panettelija, yritti itse ruveta viljelemään alkuperäistuotantoa vaikkapa petokseenkin turvautuen, ilmenee Tallinnan toisen sanomalehden, kilpailevan "Virulane" lehden toiminnasta.

J. Järven "Virulane" sanomalehden kertomusosasto läpikäy mainittuina vuosina, tarkemmin sanoen vuoden 1883 jälkeen, kiintoisan kehityksen. V. 1882 aineisto on kovin satunnaista - ensimmäisen sivun kolmanneksen käsittävä alakerta, "Liite", sisältää populääritieteellisiä artikkeleita ja Kirjameeste Seltsin puheita, kaunokirjallisen proosan osuus on vähäinen. J. Järv ei periaatteesta ole halunnut käyttää lehtensä niukkaa tilaa "ajanvietelukemiseen". Seuraavana vuonna artikkelien rinnalle alkaa ilmaantua lyhyitä käännöskertomuksia. Syyskuussa, suunnilleen niihin aikoihin kun lehden toimitukseen tuli 18-vuotias apulainen Eduard Vilde, alkaa ilmestyä pitempi käännöskertomus "Elämä ja rakkaus". Samana vuonna alakerrassa ilmestyy vielä huomionarvoinen anekdoottinen satu "Susi Vingisaaren kaivossa", johon myöhemmin pohjautui Tuglaksen novelli "Susi". ${ }^{11}$

V. 1884 "Virulane" lehden alakerta on tuntuvasti muuttunut_-sitä käytetään nyt aivan johdonmukaisesti kaunokirjallisuuden tarpeisiin. Silmiin osuu neljä Vilden käännöstä: E. Wernerin "Pater Benedikt", joka jatkuu 20 numerossa, J. D. Temmen "Kostaja" ja M. Ringin kaksi historiallista kertomusta, "Prinsessa Bonaparte" ja "Ruhtinas

${ }^{28}$ Valgus 1882/25-27; Eesti biograafiline leksikon. Toimet. A. R. Cederberg. Tartu 1926-29, s. 177.

${ }^{29}$ E. Nirk, Eduard Bornhöhe. Tallinn 1961, s. 55.

${ }^{30}$ Valgus $1885 / 16,1885 / 52$.

${ }^{31}$ Virulane 1883/11. 
ja maaorja". Siten Vilde on noussut ensimmäiselle sijalle "Virulane" lehden kertomusten kääntäjistä. Hän kääntää tietenkin saksasta, koska hän oli "kasvanut saksan kielen syleilyssä" eikä muita vieraita kieliä osannutkaan. Alkuperäisteokset sen sijaan puuttuvat "Virulane" lehden alakerrasta vielä v. 1884.

V. 1885 lehden kertomusosastossa kuitenkin tapahtuu perusteellinen käänne. Esiintyy kylläkin joukko käännöksiä, niiden mukana myös Vilden tekemiä - kuten Paul Heysen "Beatrice" ja G. Hartwigin romaani "Elämän aallot" - mutta vallitseviksi ovat päässeet alkuperäisteokset. Niihin kuuluvat pilailu "Herra Ilveksen kosiomatka", alkuperäinen novelli "Leeni", pilakertomus "Poltetut sulhasmiehet", joulupilailu "Poikamiehen jouluyö" ja kerrassaan suurena yllätyksenä romaani "'Terävät nuolet". Kaikkien näiden tekijänä on toimituksen nuori apulainen Eduard Vilde. Lisäksi ilmestyy vielä pieni alkuperäinen novelli "Rauenneet toiveet", jonka on kirjoittanut lehden julkaisija J. Järv. Lehden "liitteen" 30 numeroa on täytetty alkuperäisteoksilla, loput 22 sisältävät käännöksiä. Alkuperäisteoksille on omistettu kaksi kolmannesta palstatilasta, käännökset on tungettu yhteen kolmannekseen.

Sama suhde säilyy "Virulane" lehdessä myös seuraavana vuonna. Vilden tuotantoa edustavat v. 1886 humoreski "Pääsiäismunat" sekä novellit "Pellava-Mai" ja "Jobu". J. Järven käsialaa ovat pitkähkö kertomus "Elsa" ja joulukertomus "Luunkerääjä", erillisenä ilmestyneessä "Virulase Lisa" nimisessä liitteessä ilmestyvät lisäksi Järven "Mari Linnik" ja "Lutun Mihklin kosiomatka". J. Järven lehdessä oli siten toteutunut tärkeä periaatteellinen suunnanmuutos: kertomusosastossa tulee antaa etuoikeus alkuperäisteoksille. Sen oli tehnyt mahdolliseksi toimituksen nuoren apulaisen Vilden tuottelias kynätyö. Lehden levikki kasvoi nopeasti, ja "Virulane" nousi johtavaksi virolaiseksi sanomalehdeksi osaksi juuri suositun kertomusosastonsa ansiosta.

Tarttolainen sanomalehti "Eesti Postimees" polveutuu, kuten mainittu, J. V. Jannsenin "Perno Postimees" lehdestä, ja se jatkaa perustajansa traditiota, jonka mukaan "tarinatuvan" palstoilla on mahdollisuuksien mukaan julkaistava myös alkuperäistä proosaa Mainittuina vuosina 1882-1886 esiintyy avustajina sellaisia kirjailijoita kuin K. E. Sööt, M. Pôdder, G. E. Luiga, G. Wulff ja K. Krimm, joskin he julkaisevat vain lyhyitä proosapaloja tai runoja. Viljannin 
sanomalehti "Sakala" tyytyy mainittuina vuosina julkaisemaan pääasiassa käännöskertomuksia; alkuperäistuotteina erottuvat joukosta M. Pôdderin "Bob Ellerhein" ja A. Kitzbergin "Murheen murtama".

Tästä luettelosta ilmenee, että alkuperäistuotteiden ja käännösten keskinäiset mittasuhteet olivat eri lehtien kertomusosastoissa erilaiset. Epäselvää ei liioin liene, mistä johtui "Virulane" lehden kertomusliitteessä juuri vuoden 1883 jälkeen tapahtunut murros. Alk uperäisteosten ja käännösten vaiheilla käyty kiivas p ol e mi ikki, joka jatkui lehtien välillä rinnan käytännön työn kanssa, sisältää hyvää todistusaineistoa siitä, että juuri "Virulane" lehdessä tarjolla ollut alkuperäisen proosan runsaus pakotti muutkin lehdet tarkistamaan siihenastista kantaansa ja lopuksi mukautumaan alkuperäisteosten suosimiseen.

Vironkielinen kirjallisuusterminologia oli vielä melko kehittymätöntä, mikä aiheutti sekavuutta. "Kriitika" sanan sijaan oli hiljakkoin tullut käytäntöön Grenzsteinin käyttämä viron kielen sana "arvustus", mutta jotkin lehdet käyttivät niiden rinnalla sanaa "läbirääkimine". Vielä suurempia vaikeuksia tuottaa sana "algupärand" 'alkuperäisteos', 'originaali', joka katalysoi koko tärkeää ongelmaa koskevan keskustelun äärimmäisen riitaisaksi. "Valgus" käyttää tavallisesti termiä "esialgne jutt", myös "eesti jutt", muissa lehdissä esiintyy sellaisia ilmauksia kuin "algustöö" tai "jutt eesti rahva elust". Alkuperäisteosten propagoija ja puolustaja on tietenkin "Virulane", jonka kertomusosastossa käännöskertomukset jatkuvasti vähenevät. Pitkähkössä pääkirjoituksessa "Alkuperäisestä virolaisesta kirjallisuudesta" nimimerkin K. Kr. taakse kätkeytyvä runoilija ja arvostelija Karl Krimm suosittelee, että "myös virolaisten novellien luojat sommittelisivat teoksensa nimenomaan oman kansansa elämästä". Hän arvelee, että vähitellen lukijatkin alkavat yhä enemmän arvostaa sellaisia kertomuksia. ${ }^{32}$

"Virulane" lehden ohella myös "Eesti Postimees" korostaa alkuperäistuotannon suurta merkitystä. Siinä nähdään kansan kulttuurin mittapuu:

Ensimmäinen asia, minkä kautta jokin kansa ilmoittaa olemassaolostaan ja minkä perusteella se maailmassa yleensä jotakin merkitsee, on hyvä alkuperäinen kirjallisuus. _ _ Kaunis ja kelvollinen kirjal-

${ }^{32}$ Virulane $1886 / 22-23$. 
lisuus tekee kansan toisten joukossa arvossa pidettäväksi ja kohottaa sen sivistyskansojen joukkoon. ${ }^{33}$

Pääkirjoituksissaan lehti toistuvasti käsittelee samaa teemaa, mutta se valittaa samalla, että alkuperäinen virolainen kirjallisuus on vähäistä ja että se ei ole vielä kunnolla päässyt jaloilleen. ${ }^{34}$ Alkuperäisellä kirjallisuudella ei ole kehitysmahdollisuuksia, toteaa "Eesti Postimees", sillä "käännökset ja taas käännökset" tukahduttavat vapaan luomistyön. Valtaosa sanomalehdissä tarjolla olevasta kertomakirjallisuudesta on "vierailta vainioilta koottua, ja enimmäkseen jyviä ei ole lajiteltu akanoista". ${ }^{35}$

Kaikkein häikäilemättömin väittelijä ja demagogi on "Valgusen" julkaisija J. Kôrv, venäläistämisen keskeisiin puuhamiehiin kuuluva keinottelija, joka vaatii sanomalehden kertomusosastossa tilaa pelkästään käännöksille. Kiivaissa hyökkäyksissään toisin ajattelevia vastaan Kôrv ottaa vahvimpina herjaussanoina käytäntöön omat luomansa sanat "algupäraldama" ja "algupäraldaja". Ymmärrettävästi juuri puheena oleva aika, 1880-luvun keskivaihe, oli "Valgusen" käännösliitteille vaikeata aikaa, kun samassa kaupungissa kilpaileva "Virulane" alkuperäisten kertomustensa turvin nopeasti laajensi levikkiään, kaiken lisäksi varmaankin osaksi "Valgusen" levikin kustannuksella. Vilde, joka J. Järven rinnalla on pääsyyllinen, joutuu usein ottamaan vastaan Kôrvin "läbirääkimisiä" ja uhkailevia soimauksia. Kôrvin käsitystä alkuperäisteoksesta ja kysymyksen ympärillä lainehtinutta demagogiaa luonnehtii esim. Vilden "Leeni"-nimisen novellin ilmestyttyä käytetty puheenvuoro:

Leeni. Alkuperäinen novelli. - - Mikä siinä on alkuperäistä? - - Eihän kertomus kosioretkestä voi vaatia alkuperäisen nimeä, sehän on jo ammoin sitten kyllästyttänyt lukijat, ja muuta siinä taas ei ole. Vai onko se alkuperäistä, että Kaarel heitti Joosepin mereen ? 36

Kôrv väittää, että jos Vilden novelli "Leeni" on alkuperäinen, silloin jouduttaisiin pitämään alkuperäisinä myös kaikkia ryöstö-, tappoja hevosvarkausjuttuja, joita "sanomalehdet kuhisevat". Tällainen käsitys kirjallisuuden alkuperäisyydestä teki Kôrville mahdolliseksi

33 Eesti Postimees 1884/31.

${ }^{34}$ Eesti Postimees 1882/23; Postimees 1887/43.

${ }^{35}$ Eesti Postimees 1899/53.

${ }^{36}$ Valgus 1885/16. 
pitää "Valgus" lehden saksan ja venäjän kielestä käännettyjä kertomuksia "alkuperäisempinä". Arvostelunsa Vilden novellista hän lopettaa varoitukseen: "Olisi toivottavaa, ettei tällaisia hirmuisia kertomuksia, niihin luettuina myös mainitun "alkuperäisen" kertomuksen tapaiset jutut, tästälähin enää ilmestyisi sanomalehdissä."

Kôrv todistelee myös, että esim. Viron historiasta on mahdotonta kirjoittaa alkuperäistä teosta (jättäen viisaasti sanomatta, että sen voi tehdä ainoastaan Kôrv):

Jos joku kirjoittaa "alkuperäisen romaanin" Viron menneisyydestä, niin hän tahtonee, mikäli hän yleensä osaa ajatella, kaiketi sanoa, että Viron menneisyys alkaa vasta tästä romaanista, sillä muutenhan menneisyyttä käsittelevä romaani ei voisi olla alkuperäinen, vaan se olisi menneisyydestä otettu. Tällä tavalla me heikolla järjellämme käsitämme tämän ajatuksen. Ja niin sanoo myös vieraskielinen sana logiikka. ${ }^{37}$

Tämän demagogian lisäksi Kôrv saattaa alkuperäisten kertomusten kirjoittajat plagioimista koskevan epäluulon alaisiksi väittäen, että "saksan kielestä käännetään kaikkein kurjimpia kynäntuotteita ja julkean omahyväisesti julkaistaan niitä niin sanottujen 'alkuperäisten kertomusten' ja 'alkuperäisten romaanien' nimellä". Alkuperäisiä teoksia hän nimittää petokseksi, tekijät tahtovat saada niillä "vain rahaa ja rahaa kansan taskusta." ${ }_{38}$ Juhan Liiv asettuu Kôrvin apulaiseksi "Valgusen" käymässä mustaamiskampanjassa ottaen käsiteltäväkseen Vilden kertomuksen "Kaksi sormea". Kirjailijasta puhuessaan Liiv sanoo, että "hra Vilde on kyllin tuttu 'alkuperäisistä kertomuksistaan'". Arvostelijan mielestä Vilden teosten siveellinen taso on alhainen. ${ }^{39}$ Myös Kôrv on jatkuvasti huolissaan kansan moraalin puolesta, jota alkuperäinen kirjallisuus hänen mielestään epäilemättä vahingoittaa. Kôrv arvelee, että nuoret ihmiset etsivät lukemastaan kuvauksia epämoraalisista ihmisistä jäljitelläkseen sitten näiden paheellisia tekoja, ja juuri tällaisia kuvauksia alkuperäinen kirjallisuus Kôrvin mielestä tarjoaa. ${ }^{40}$ Koska siis alkuperäinen kirjallisuus tuo mukanaan kaikkinaista pahaa eikä mitään hyvää, Kôrv lopuksi tuo

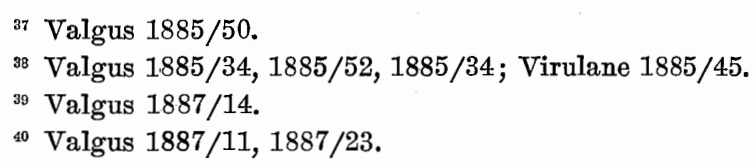


esiin nerokkaan ehdotuksen: virolaiset kynänkäyttäjät lopettakoot kokonaan alkuperäisten teosten kirjoittamisen ja ruvetkoot kaikki kääntäjiksi:

Olisi hyvä ja kiitettävä asia, jos Viron nuoret kirjailijat kerran kuitenkin ottaisivat neuvosta vaarin ja muuttuisivat alkuperäilijöistä hyviksi kääntäjiksi. ${ }^{41}$

Hänen mielestään virolaisten proosakirjailijoiden pitäisi kokonaan omistautua "kelvollisten vieraskielisten kirjateosten kääntämiseen. Se olkoon meidän toivomuksemme tänä surullisena alkuperäisten kirjasienien kukoistusaikana". Tämän idean syntyyn on Kôrvin mukaan vaikuttanut se, että "viime aikoina alkuperäileminen on taas tullut oikein muodiksi".

Kôrvin panettelut eivät kuitenkaan pystyneet lopettamaan alkuperäistä virolaista proosakirjallisuutta, virolaiset prosaistit eivät ruvenneet kääntäjiksi. Kävi täsmälleen päinvastoin: Kôrvin itsensä oli pakko yrittää alkuperäisen proosan kirjoittamista. Se tapahtui tietenkin hänelle luonteenomaisella tavalla: petokseen turvautuen. Jo v. 1885, kun naapurilehti "Virulane" julkaisi joukon Vilden alkuperäisiä kertomuksia, "Valgusessa" ilmestyi Kôrvin lyhyehkö "virolainen kertomus", ja samaa menettelyä jatkaen hän myöhemminkin pani käännöstensä alaotsikoksi "virolainen kertomus", minkä piti mer. kitä alkuperäisteosta. Pari vuotta myöhemmin Kôrvin toiminta kuitenkin johti todelliseen skandaaliin. "Valgus" lehdessä ilmestyi vuoden 1887 alussa kertomus "Kiireinen kosinta. Virolainen kertomus. Tarina kaupungista. Kirjoittanut Jakob Kôrv". Painattaessaan teoksen kirjaksi Kôrv täsmensi alaotsikkoa: se oli nyt "tarina Tallinnasta". Kenenkään mieleen ei voinut juolahtaa, ettei virolainen kertomus, joka kuvaa Tallinnan elämää, olisi alkuperäinen, etenkin kun vielä tekijän nimi oli selvästi merkitty näkyviin. "Postimees" ei anna teokselle suurta arvoa - jo ennen kuin se on ehtinyt loppuun asti ilmestyä lehden kertomusosastossa, sanotaan siitä, että kertomus on "kipeä korvapuusti virolaiselle kirjallisuudelle". ${ }^{42}$ Petoksen ilmitulo kestää kauan, mutta lopuksi ilmoitetaan, että Kôrvin "virolainen kertomus" ei ole mikään muu kuin käännös André Theuriet'n romaanin saksankielisestä käännöksestä "Gérards Heirat" eikä sillä ole

41 Valgus $1888 / 41$.

42 Postimees 1887/9. 
mitään tekemistä Tallinnan kanssa. ${ }^{43}$ Sillä välin "Valgusessa" ehti kuitenkin tulla julki uusi, vieläkin surkuhupaisempi "eesti jutt". Samana vuonna 1887 alkoi nimittäin ilmestyä "Luigemäen Olli. Kuvauksia Viron menneisyydestä. Kirjoittanut Jakob Kôrv". Tarinan ilmestymistä lehden kertomusosastossa säesti epätavallisen patrioottinen mainostus, vaikka Kôrv tavallisesti soti kaikkia kansallisia yrityksiä vastaan. Uuden plagiaatin yhteydessä hän katsoi sopivaksi soitella juuri isänmaallisuuden kieliä:

"Valgusen" toimittajan omasta kynästä jatkuu isänmaallinen Viron historian kuvaus Luigemäen Olli, josta tulee pitempi historiallinen kertomus virolaisena alkuperäisteoksena ja joka tutustuttaa kansaamme vanhempiemme tuskalliseen menneisyyteen ja uljaisiin tekoihin. $^{44}$

Kôrv väittää samassa yhteydessä tulleensa nyt ymmärtämään historiallisen kirjallisuuden ja alkuperäisteosten suuren arvon, ja ilmestyvässä kertomuksessa hän sanojensa mukaan on "pyrkinyt osoittamaan rakkautensa Viron historiaan ja kirjallisuuteen". Julkaistessaan teoksen kirjana hän on vielä täsmentänyt alaotsikkoa, jonka mukaan nämä "kuvaukset Viron menneisyydestä" kertovat vuosista 1217-1224. Kôrv teki plagiaatillaan karhunpalveluksen Eesti Kirjameeste Seltsiin kuuluville ystävilleenkin, jotka jopa palkitsivat hänen teoksensa antaen siitä v. 1890 ensimmäisen palkinnon. Tallinnan venäläinen lehti "Revelskija Izvestija", jossa myös oli Kôrvin ystäviä, oli palkitsijoiden kanssa samalla tasolla ja kiitteli teosta alkuperäiseksi ja huomattavaksi saavutukseksi. Mutta lopuksi tämäkin petos tuli päivänvaloon. Kirja oli puheena Eesti Ưliôpilaste Seltsissä, ja "Postimees" ilmoitti, että "Luigemäen Olli" on käännös. ${ }^{45}$ Muutkin lehdet irvistelivät. Niinpä esim. "Olevik" totesi kirjoituksessa "Ollisetä penkin alla", että "juttu on ranskasta saksaan käännetty ja siitä viroksi väännetty. Siinä on Jumala paratkoon kysymys intiaaneista." 46 Kôrvin "kuvauksia Viron menneisyydestä 1217-1224" ei ollut mikään muu kuin Chateaubriandin intiaanikertomus "Atala".

${ }^{43}$ Postimees $1896 / 76$.

${ }^{44}$ Valgus 1888/1.

45 Postimees 1894/25.

46 T. Kaljo, Jakob Kõrv’i "Luigemäe Olli" algupärast. Eesti Kirjandus 1930, s. $353-354$. 
Sitkeästä vastarinnasta huolimatta virolaisten sanomalehtien kertomusosastoissa tapahtui sittenkin kehitystä alkuperäisteosten eduksi — käännösten tarmokkaat puolustajat joutuivat perääntymään. Erityisen selvästi suunnanmuutos tuli näkyviin "Virulane" lehdessä 1880-luvun keskivaiheilla. Vilde osoitti siinä teoillaan, että on mahdollista tarjota följetongina myös omaa kirjallisuutta ja syrjäyttää käännökset, ja hän sai myös lukijakunnan puolelleen. Käännöskirjallisuuden pitkäaikainen valta-asema ei kuitenkaan mennyt ohi jättämättä pahoja jälkiä. Vilde joutuu vielä v. 1891 toteamaan:

Meidän nuoret alkuperäiskirjailijamme ovat vielä niin vieraissa kammitsoissa — - liekapölkyt jalassa ja ahtaat päitset päässä. - päävika näyttää olevan, että he syrjäyttävät kotiseutunsa ja kuvaavat sellaisten seurapiirien, maiden ja kansojen elämää, joita he eivät itse laisinkaan tunne. ${ }^{47}$

Pahimmasta sättijästään .J. Kôrvista Vilde huomauttaa samassa yhteydessä:

hän ristii kertomuksensa komealla leimalla "virolainen kertomus", mutta juuri tämä kynäilijä on töiltään kaikkein avuttomin, kaikkein tylsin ja luonteettomin, hän ei ole vielä päässyt kirjoitustyön aakkosia pitemmälle.

Mutta käännöstenkään kiittelijät eivät olleet tuohon aikaan vielä suinkaan vaienneet. Kôrvin onnistui vieläpä tuhota kilpailijansa "Virulane" ja kanteluiden perusteella karkotuttaa sen julkaisija Järv kotimaastaan. "Postimees" valittaa, että alkuperäisiä kertomuksia vastaan hyökkäillään ankarasti ja että "herjataan jokaista kynänkäyttäjää, joka vain rohkenee kertoa jotakin Viron kansan elämästä". ${ }^{48}$ Vuosisadan vaihteeseen mennessä päästiin kuitenkin niin pitkälle, että lehdet pyrkivät julkaisemaan kertomusosastossaan ensi kädessä alkuperäisteoksia. Kôrv ja hänen kaltaisensa sanomalehdentoimittajat olivat jo jääneet menneisyyteen. Niin ollen oli luonnollista, että K. Päts hankki perusteilla olevan sanomalehti "Teatajan" kaunokirjallisen osaston toimittajaksi Eduard Vilden arvioiden lehden hyödyksi oikein hänen alkuperäisten teostensa suuren kansansuosion. Ja niin saattoivat Vilden suuret historialliset romaanit ilmestyä

47 Postimees 1891/21.

48 Postimees 1891/180. 
lehden kertomusosastossa ja saada osakseen lukijakunnan "suurenmoisen suosionhälyn", ilman että kukaan olisi enää nostanut esiin alkuperäisteosten tai käännösten etuoikeuttamisen ongelmaa.

\section{Herbert SALu: Das Feuilleton der estnischen Zeitungen am Ende des vorigen Jahrhunderts}

Die Journalistik in Estland nahm spät ihren Anfang. Die erste Zeitung in der Landessprache, abgesehen von ein paar kurzlebigen Versuchen, nahm ihr Firscheinen erst mit dem Jahre 1857 auf; es war J. W. Jannsens "Perno Postimees ehk Näddalileht”' (Pernauer Postbote oder Wochenblatt). Die Lesekunst war im Lande wegen Mangel an Volksschulen nur wenig verbreitet und damit war die Nachfrage nach Zeitungen unbedeutend. Ein anderer paralysierender Faktor war die Antipathie der russischen Behörden gegen ein Zeitungswesen für die Bauernbevölkerung. Im russischen Grenzgouvernement Estland war es sehr schwer, die Druckerlaubnis zu erhalten.

Dank der Zähigkeit und Initiative der einheimischen Bevölkerung stand das Niveau des Kulturlebens in Estland jedoch ein wenig über dem des eigentlichen Russlands. Im Jahre 1870, als die Lesekunst in. Westeuropa schon beinahe allgemein verbreitet war - in Deutschland gab es nur 2,37\%, in Schweden $1,90 \%$ Analphabeten in der Gesamtbevölkerung -, waren in Russland noch 78,66\% der Bevölkerung des Lesens unkundig. In den letzten Jahrzehnten des Jahrhunderts trat in Estland eine merkliche Besserung ein, und vor der Jahrhundertwende stand das Gouvernement mit 79,9\% Lesekundigen an der Spitze von ganz Russland. Die Zahl der Zeitungleser nahm schnell zu, und damit erschienen auch neue Zeitungen; Lizenzen wurden unablässig beantragt.

Einen wichtigen Teil der estnischen Zeitung bildete schon gleich von Anfang an das Feuilleton, und seine Bedeutung stieg zugleich mit der Expansion des Journalismus. Das war eine günstige Tatsache für die Belletristik, besonders für die Prosaliteratur. Diese nahm ihren ersten Aufschwung gerade im Schutze des Journalismus. Alle wesentlichen Erzählungen, Novellen und Romane der beginnenden estnischen Prosa sind erst als Feuilleton in Zeitungen erschienen und dann als Bücher gedruckt worden.

Einen wichtigen Wendepunkt in der Entwicklung des Feuilletons der estnischen Zeitungen bildete die Mitte der 1880-er Jahre. Zu dieser Zeit existierten schon etwa zehn versehiedene Zeitungen und der Umfang des Feuilletons war damit nun, 30 Jahre nach Jannsens Erstlingswochenblatt, beinahe auf das 50-fache angewachsen. Es entspann sich aber eine heftige Polemik darüber, mit welchen Texten diese Spalten gefüIlt werden sollten, und über das Wesen des estnischen Feuilletons im allgemeinen. Die Hauptfrage war: Soll eine Zeitungserzählung ein Originalwerk oder eine Übersetzung sein. Da Übersetzungen viel billiger und leichter zu beschaffen waren, brachten die meisten Zeitungen nur Übersetzungen.

Das Blatt "Virulane" in Reval nahm eine radikal abweichende Haltung 
ein. Im Herbst 1883 wurde der 18-jührige Eduard Vilde als Gehilfe in die Redaktion aufgenommen, der bald unter dem Strich seine eigenen Erzählungen veröffentlichte. In den nächsten Jahren wurden dureh das Wirken Vildes im Feuilleton des "Virulane" die Ưbersetzungen beinahe gänzlich verdrängt. Die Leserschaft nahm Vildes Erzählungen ausserordentlich günstig auf und die Verbreitung des Blattes nahm schnell zu. Der Herausgeber des konkurrierenden Blattes "Valgus" in Reval, J. Kõrv, war ein eifriger Verteidiger der Übersetzungen und griff Vilde und seine Originalerzählungen rücksichtslos an. Bald war auch Kõrv gezwungen einzulenken; er versuchte erst seine Übersetzungen unter seinem eigenen Namen als Originalwerke anzubieten. Der Betrug kam bald ins Tageslicht und wurde für ihn zu einer schweren Blamage. Allmählich folgten die estnischen Blätter dem Beispiel der Zeitung "Virulane" und brachten im Feuilleton vorwiegend Originalerzählungen. Im Anfang unseres Jahrhunderts publizierten sie schon grosse und wertvolle Originalromane. 